\title{
PENERAPAN FONETIK AKUSTIK DALAM BACAAN MAD ALQURAN (STUDI KASUS PADA QIRAAT QARI INTERNASIONAL)
}

\author{
Muflihana Dwi Faiqoh ${ }^{1,2}$ \\ Moh. Masrukhi ${ }^{1}$ \\ ${ }^{1}$ Fakultas Ilmu Budaya Universitas Gadjah Mada \\ ${ }^{2}$ Email: mdwifaiqoh@ymail.com
}

\begin{abstract}
The time duration is one of the important acoustic features discussed among the researchers. This article presents the results of a study of variation and duration of madd (long vowel). The data were obtained by downloading of two Quran reciterswho are Muammar Zainal Asyiqin and Maria Ulfahfrom the website.To investigate the duration of the types of madd, it uses an acoustic phonetics approach andto measure the acoustic duration of these madd, it employs the computer program 'Praat'.Among the most important results, it is noted that Maria has the longer duration than Muammar does. Furthermore, the investigation of madd duration is addressed well, followed by the analysis for each madd.
\end{abstract}

Keywords: Madd, long vowel, Quran reciter, Acoustic phonetics, Praat

$$
\begin{aligned}
& \text { ملخص } \\
& \text { المد (طول الصوت اللغوي) هو واحد من الملامح الأكوستية الهامة التي نوقشت بين الباحثين. هذه المقالة هي } \\
& \text { نتائج دراسة التباين عن طول الصوت اللغوي. وطريقة تحصيل البيانات هي طريق تحميل قرائتين من قراء القرآن }
\end{aligned}
$$

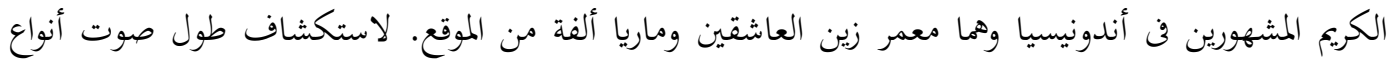

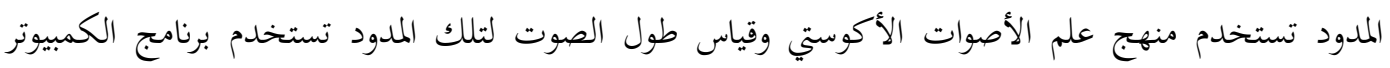

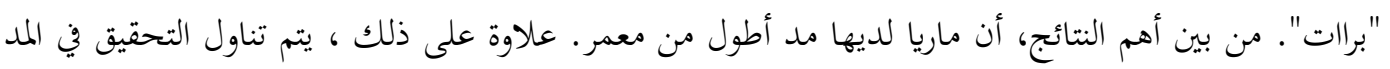

$$
\begin{aligned}
& \text { بشكل جيد، ويتبعه تحليل لكل مد. } \\
& \text { الكلمات المفتاحية : المد، قارئ القرآن الكريم، علم الأصوات الأكوستي، برات (Praat) }
\end{aligned}
$$

\section{A. Pendahuluan}

Di dalam Alquran, terdapat bermacam-macam jenis bacaan yang masing-masingnya memiliki hukum bacaan tersendiri. Hukum bacaan dalam Alquran merupakan fokus dari ilmu Tajwid, yaitu suatu ilmu yang khusus mengupas hukum dan cara membaca Alquran secara benar dan tartil.

Di antara belasan jenis bacaan dalam ilmu Tajwid, bahasan tentang mad menjadi topik yang menarik untuk dikaji. Hal ini dikarenakan masih banyak ditemukan kekeliruan dalam membaca bacaan mad. Mad sendiri adalah bacaan yang dipanjangkan disebabkan oleh huruf mad. Jenis mad ada banyak macamnya dengan durasi panjang yang berbeda-beda. Begitu juga orang-orang yang membacanya berbeda-beda dalam hal durasi. Jenis mad A, orang yang berbeda memungkinkan membaca mad tersebut dengan durasi yang berbeda pula.

Dua qari Indonesia yang menjadi subjek penelitian ini adalah Muammar Zainal Asyiqin (MZA) dan Maria Ulfah (MU). Muammar, salah satu qari terbaik 
Indonesia yang berasal dari Pemalang. Demikian pula Maria, salah satu qari terbaik Indonesia yang berasal dari Lamongan. Prestasinya di dunia qiraat sudah sampai di kancah internasional dan membuat kedua nama itu menjadi salah satu yang diperhitungkan di negeri ini.

Sejumlah penelitian terkait durasi bunyi diantaranya dilakukan oleh Zangar dkk (2018) dalam artikelnya yang berjudul "Duration Modeling Using DNN for Arabic Speech Synthesis". Penelitian ini menggunakan algoritme DNN dengan mengkomparasikan beberapa model, yaitu MERLIN dan HTS, untuk mendeskripsikan durasi bunyi bahasa Arab. Bunyi-bunyi tersebut adalah vokal pendek, vokal panjang, konsonan sederhana, dan konsonan geminasi (syadd/dobel). Hasil penelitian tersebut mengemukakan bahwa setiap jenis bunyi diukur dengan model algoritme yang menampilkan hasil kumpulan validasi terbaik. DNN sendiri merupakan kepanjangan dari Deep Neural Network, atau biasa disebut Artificial Neural Network (ANN/Jaringan Syaraf Tiruan) yaitu teknik dalam Machine Learning (ML), salah satu metode dari Kecerdasan Buatan (Artificial Intelligence) yang menirukan syaraf manusia (Ahmad, 2017:2). Secara singkat, DNN adalah hitungan matematis atau tumpukan fungsi matematika. Lebih jelasnya dapar mengacu ke Bengio (2009) dan Bengio, Goodfellow, dan Courville (2015).

Penelitian lainnya dilakukan oleh Tsukada dengan judul "An Acoustic Comparison of Vowel Length Contrast in Arabic, Japanese, and Thai: Durational and Spectral Data" (2009). Penelitian ini mengkaji karakteristik fonetik akustik dari panjang vokal dari bahasa Arab, Jepang, dan Thai. Dalam pengukurannya, digunakan piranti CoolEdit dan ESPS. Penelitian ini menghasilkan kesimpulan bahwa durasi bunyi vokal pendek dan bunyi vokal panjang masing-masing bahasa jelas berbeda, bunyi vokal panjang dua kali lebih panjang daripada bunyi vokal pendek. Selain itu, bahasa Thai, baik vokal pendek maupun panjang, durasinya lebih panjang dari bunyi vokal bahasa Arab dan Jepang.

Penelitian serupa dilakukan oleh Yaman (2016) dalam disertasinya yang berjudul 'Modus Tuturan BahasaArab oleh Pembelajar Bahasa Arab di Medan: Kajian Fonetik Eksperimental'. Penelitian tersebut menggunakan Praat dalam menganalisis frekuensi, intensitas, dan durasi tuturan bahasa Arab pada modus interogratif, deklaratif, dan imperatif yang diujarkan oleh pembelajar bahasa Arab yang kemudian diperbandingkan dengan penutur asli bahasa tersebut. Hasil penelitian menunjukkan bahwa perbedaan frekuensi, intensitas, dan durasi yang terjadi antara pembelajar bahasa Arab dan penutur asli disebabkan perbedaan sistem bunyi bahasa Arab dan bahasa Indonesia.

Berdasarkan uraian yang telah dipaparkan, penelitian tentang durasi bacaan mad menjadi penting untuk dilakukan karena belum ada penelitian serupa yang dapat dijadikan kaidah bagi masyarakat muslim khususnya dalam penerapannya ketika membaca Alquran. Oleh karena itu, permasalahan dalam kajian ini adalah bagaimana durasi bacaan mad MZA dan MU. Penelitian ini merupakan penelitian awal untuk memperoleh perbedaan durasi bacaan mad antara kedua qari tanpa menjelaskan faktor yang menyebabkan terjadinya perbedaan tersebut.

Sugiyono (2003:3) menyebutkan bahwa esensi dari bahasa lisan adalah gejala akustiknya. Bahasa lisan dipandang sebagai sebuah gejala akustik yang merupakan realisasi semantis sebuah bahasa.Kajian ini memfokuskan pada bunyi bacaan mad yang berjumlah 15 jenis. Jenis-jenis mad ini terkandung dalam pembahasan ilmu tajwid, yaitu ilmu yang menjelaskan kaidah dan hukum dalam membaca Alquran. Kajian tentang bunyi bahasa ini terangkum dalam ilmu fonetik. Ilmu fonetik dalam bahasa Arab dikenal dengan sebutan 'ilmul-'ashwat' علم الأصوات, yaitu cabang ilmu bahasa yang mengkaji pengucapan bunyi-bunyi bahasa, perpindahannya, dan pengenalannya (alKhuli, 1982:112).

Dari sudut pandang fonetik, sebuah tuturan terdiri dari unsur segmental 
dan suprasegmental/prosodi. Secara umum, unsur segmental meliputi bunyi vokal dan konsonan. Adapun durasi adalah salah satu ciri dari prosodi selain intonasi, tekanan, dan titinada suara (Marsono, 2013:2; Sugiyono, 2003:25). Istilah durasi sendiri digunakan dalam ilmu fonetik yang mengacu pada lama waktu yang berkaitan dengan artikulasi bunyi atau silabel. Durasi atau ath-thul (الطول) dihitung dengan satuan waktu seperti milidetik (Crystal, 2008:159). Durasi bunyi vokal bahasaArab dibedakan menjadi dua, yaitu bunyi vokal pendek ( harakat qashirah/حركات قصيرة) dan bunyi حركات vokal panjang (harakat thawilah/ طويلة). Dalam penelitian ini, yang dikaji adalah bunyi vokal panjang. Vokal panjang bahasaArab ada tiga (3), yaitu [a>] yang dilambangkan dengan alif ['], bunyi $[\mathrm{u}>$ ] dilambangkan dengan wawu [9], dan bunyi [i>] yang dilambangkan dengan $y a^{\prime}[$ []. Berikut disajikan tabel yang memuat bunyi vokal bahasaArab.

Tabel 1

Bunyi Vokal Bahasa Arab

\begin{tabular}{|c|c|c|c|}
\hline & \multicolumn{2}{|c|}{$\begin{array}{c}\text { Lambang } \\
\text { Bunyi }\end{array}$} & Nama Bunyi \\
\hline \multirow{3}{*}{$\begin{array}{l}\text { Harakat } \\
\text { Qashirah }\end{array}$} & [a] & [-'] & فتحة/ fathah \\
\hline & {$[\mathrm{u}]$} & {$[\stackrel{?}{-}]$} & ضammah / \\
\hline & [i] & {$[-]$} & كسرة/kasrah \\
\hline \multirow{3}{*}{$\begin{array}{l}\text { Harakat } \\
\text { Thawilah }\end{array}$} & {$[\bar{a}]$} & {$[1]$} & ألف alifl \\
\hline & {$[\overline{\mathrm{u}}]$} & [g] & واو \\
\hline & [i] & ]ي] & ياء / \\
\hline
\end{tabular}

Beberapa piranti yang digunakan untuk mengukur durasi atau ciri prosodi lainnyaadalah spektograf, atau program komputer seperti CRSE dan Praat. Penelitian ini menggunakan pendekatan instrumental, yaitu memanfaatkan bantuan alat ukur yang akurat. Alat ukur yang dipergunakan dalam penelitian ini adalah perangkat lunak Praat seri 6037.

Praat adalah sebuah program komputer untuk menganalisis dan mensintesis bunyi sebuah tuturan. Dalam pendahuluannya dalam artikel milik Boersma dan van Heuven (2001:1), Goedemans menyatakan bahwa popularitas Praat meningkat pesat seiring banyaknya penelitian tentang ciri akustik sebuah bunyi. Dia juga menambahkan bahwa program ini mudah digunakan serta lebih dari 5000 pengguna di 99 negara telah memanfaatkannya. Praat banyak dimanfaatkan oleh para linguis seperti ahli fonetik, fonologi, dan ahli sintaksis, untuk mensegmentasi rekaman tuturan. Program ini dapat digunakan untuk merekam bunyi atau untuk membaca file rekaman. Adapun mad, sebagai objek yang dianalisis, adalah bacaan panjang, atau memanjangkan suara bacaan menurut aturan-aturan tertentu dalam membacaAlquran. Secara umum, pembagian mad dalam ilmu Tajwid berdasarkan tempo panjang bacaan diklasifikasikan menjadi empat kelompok. Pertama, kelompok mad yang dibaca 2 harakat (1 alif) terdiri atas mad Ashli/Thabi'i, mad 'Iwadh, mad Badal, mad Shilah Shughra, mad Tamkin, dan mad Lazim Mukhaffaf Harfi. Kedua, mad yang boleh dibaca 2/4/6 harakat (1/2/3 alif) termasuk di antaranya mad 'Aridh lisSukun dan mad Layyin. Ketiga, mad yang dibaca panjang 4-5 harakat (2-2,5 alif) yaitu mad Wajib Muttashil, mad Jaiz Munfashil, dan mad Shilah Kubra. Keempat, kelompok mad yang dibaca 6 harakat ( 3 alif) terdiri atas mad Lazim Mukhaffaf Kilmi, Lazim Mutsaqqal Kilmi, Lazim Mutsaqqal Harfi, dan mad Farq (Hiluz, 2008:91).

Data yang digunakan dibatasi pada rekaman bacaan Alquran/murattal yang mengandung jenis-jenis mad dari dua qari yang berasal dari Indonesia, MZA dan MU. Pemilihan subjek penelitian ini ditentukan dengan teknik purposive sampling yang didasarkan pada beberapa kriteria di antaranya: (a) memiliki organ wicara lengkap, (b) mahir dalam membaca Alquran dan dipercaya sebagai seorang qari/qariah, (c) dikenal baik secara luas oleh banyak kalangan, khususnya secara internasional, dan (d) rekaman bacaan murattalnya dapat 
diperoleh dengan mudah dengan kualitas suara yang bagus. Data yang dikumpulkan berupa rekaman bacaan beberapa surat dalam Alquran yang bukan merupakan rekaman bacaan dalam shalat. Rekaman bacaan MZA diunduh dari laman https://m.facebook.com/notes/mastaahmad/download-mp3-murottal-al-quranh-muammar-za-lengkap-30juz/1429255940625923/, sedangkan rekaman bacaan MU diperoleh dengan mengunduh dari situs youtube channel/saluran milik Much Nasih Amin pada laman https://www.youtube.com/channel/UCPX kzbpvTOzguhHMgaeAsfw. File audio rekaman dilakukan pemotongan secaradaring melalui laman https://mp3cut.net/id/. Hasil rekaman yang telah dicut kemudian diperdengarkan beberapa kali untuk memastikan pemenggalan cuplikan yang mengandung mad tidak mengurangi atau menambah waktu durasi. File yang telah dicut disimpan untuk kemudian ditranskripsi secara ortografis dan diukur durasinya dengan memanfaatkan program komputer Praat. Pemilihan program ini karena dapat digunakan dengan mudah dan telah memenuhi kebutuhan penelitian akustik dengan akurasi yang tinggi. Selain itu, program ini tidak memerlukan kapasitas penyimpanan yang besar.

Langkah-langkah yang dilakukan dalam analisis menggunakan program Praat adalah: pertama, proses digitalisasi yaitu dengan memasukkan data rekaman ke dalam program tersebut yang kemudian dilakukan pembersihan data dengan membuang bagian-bagian yang tidak diperlukan, dalam hal ini bagian yang tidak mengandung bacaan mad. Kedua, segmentasi data dilakukan dengan memberi tanda pada data-data yang telah melaui proses digitalisasi, kemudian dipilah menjadi segmen-segmen tunggal (silabel). Hasil segmentasi disimpan dalam bentuk file textgrid. Langkah ketiga dilakukan dengan mengukur durasi dari segmen-segmen tunggal tersebut. Pada proses ini, dilakukan manipulasi data tuturan (manipulation). Hal ini dilakukan untuk memperoleh gambar kurva melodik data bunyi yang dianalisis. Pada proses manipulasi, dilakukan stilisasi nada (stylize pitch). Selanjutnya, mengekstraksi hasil manipulasi (pitch tier) dan menyalinnya dalam praat picture. Data yang muncul berupa kurva melodik kontur nada dan durasi kemudian disalin ke dalam Microsoft Word. Keempat, masingmasing data yang telah dilakukan pengukuran dicatat dan diklasifikasikan berdasarkan jenis mad kemudian diperbandingkan. Hasil analisis kemudian disajikan dalam laporan penelitian berupa artikel publikasi.

\section{B. Pembahasan}

\section{Durasi Bacaan Mad}

Sebagaimana telah disebutkan pembagian kelompok jenis mad menjadi 4 kelompok, berikut penjabaran masingmasing jenis mad dari setiap qari. Tabel 2 berikut merupakan hasil analisis Praat yang menampilkan perbandingan durasi mad dari masing-masing qari.

Tabel 2

Durasi Bacaan Mad

\begin{tabular}{|c|c|c|c|}
\hline \multirow{2}{*}{ No } & \multirow{2}{*}{ Kelompok Mad } & \multicolumn{2}{|c|}{ RerataDurasi (detik) } \\
\hline & & MZA & $\mathrm{MU}$ \\
\hline 1 & Mad & ,7218 & 0,7528 \\
\hline 2 & $\begin{array}{c}\text { Mad } \\
\text { Hara }\end{array}$ & 014 & 2,6 \\
\hline 3 & 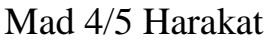 & & 2,03 \\
\hline 4 & ad 6 Harakat & 2,564 & 2,699 \\
\hline
\end{tabular}

Pada tabel di atas dapat dilihat adanya perbedaan durasi waktu pelafalan bacaan keempat kelompok jenis mad oleh kedua qari. Perbedaan tersebut tampak bervariasi. Namun, secara umum dapat disarikan bahwa data pada variabel MU memiliki durasi yang lebih panjang dibandingkan MZA. Data tersebut tampak lebih jelas terlihat pada grafik berikut. 


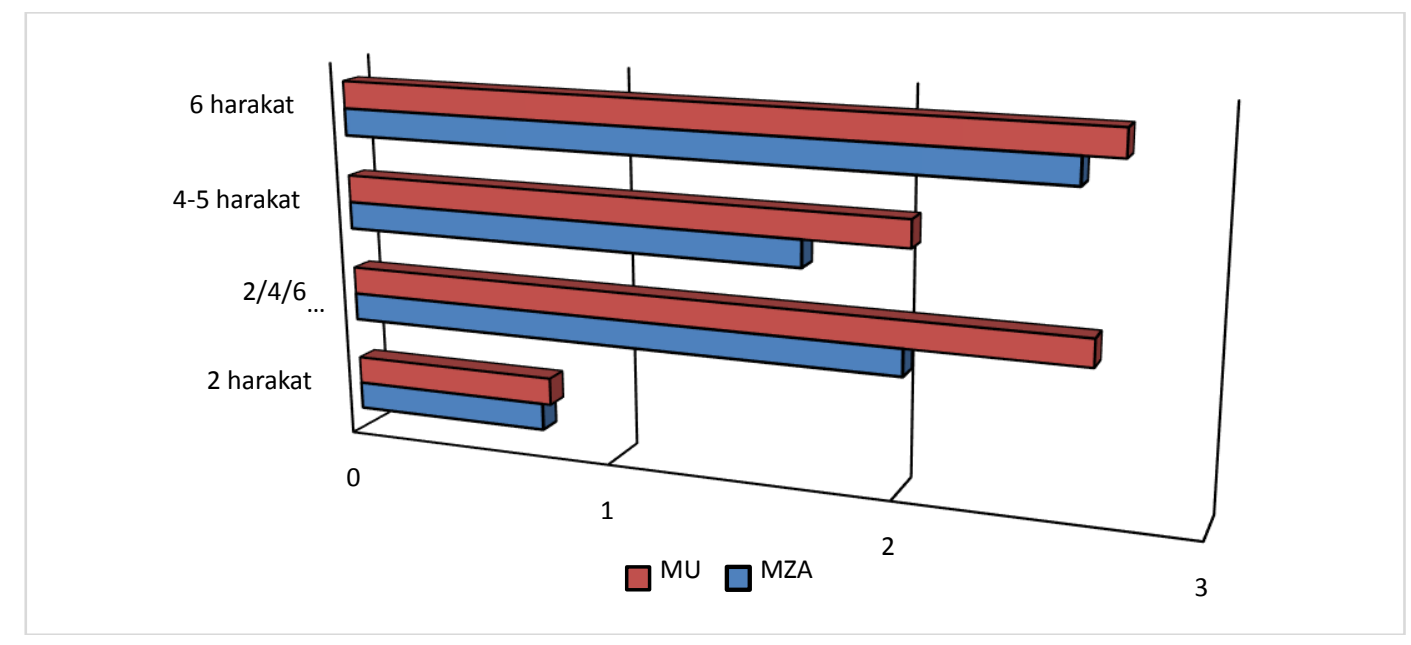

Pada diagram di atas, garis vertikal menunjukkan empat kelompok jenis mad, yaitu kelompok mad 2 harakat, 2/4/6 harakat, 4-5 harakat, dan 6 harakat. Durasi bunyi yang diujarkan oleh qari ditunjukkan dengan gambar batang: (1) batang berwarna merah untuk durasi bunyi MU, (2) Batang berwarna biru untuk durasi bunyi MZA. Selanjutnya, garis horizontal menunjukkan angka rerata durasi bunyi dalam hitungan detik. Pada diagram tersebut, dapat dilihat adanya perbedaan durasi antara MU dan MZA.

Rekaman ayat-ayat Alquran yang diunduh di antaranya QS 10:51 yang mengandung madThabi'i dan madLazim Mukhaffaf Kilmi, QS 1:3 mengandung mad Badal, mad Tamkin pada QS 33:7, QS 8:25 mengandung mad Lazim Mutsaqqal Kilmi, mad 'Iwadh pada QS 100:5, mad Farq pada QS 6:143, mad Shilah Shughra pada QS 101:9, mad Lazim MutsaqqalHarfi pada QS 7:1, mad 'Aridh lis-Sukun pada QS 95:2, mad Layyin pada QS 106:4, mad Wajib Muttashil pada QS 88:18, mad JaizMunfashil pada QS 109:1, serta mad Shilah Kubra pada QS 104:3.

Setiap jenis mad ditampilkan durasi tiga contoh dari tiga ayat yang berbeda. Dari hasil pengukuran durasi ketiga ayat setiap jenis mad, dihitung mean atau rerata. Rerata yang diperoleh dari masing-masing jenis mad kemudian dihitung rerata semua jenis mad. Rerata durasi akhir yang diperoleh dihitung dari total rerata semua jenis mad kemudian dibagi total mad dalam setiap kelompoknya. Selanjutnya, rerata tiap kelompok mad diperbandingkan antar qari dalam tabel secara berurutan.

$$
\bar{x}=\frac{\sum \bar{x}}{\sum n}
$$

\section{Durasi Mad yang Dibaca 2 Harakat}

Mad yang termasuk dalam kelompok ini adalah:

a. Mad Thabi'i(MT), mad yang terdapat pada huruf yang berharakat fathah ketika bertemu huruf alif (I), huruf berharakat kasrah bertemu dengan huruf ya (ي), dan huruf berharakat dhammah bertemu dengan huruf wawu (و),

b. Mad 'Iwadh (MI), memanjangkan bacaan selama 2 harakat pada tanwin fathah yang berada di akhir ayat atau di akhir bacaan ketika waqaf, dan menggantinya dengan fathah tanpa tanwin

c. Mad $\operatorname{Badal}(M B) \quad$ artinya memanjangkan bacaan selama 2 harakat pada huruf yang berharakat fathah berdiri,

d. Mad Shilah Shughra(MSS) adalah huruf Ha dhamir (kata ganti) tunggal berharakat dhammah atau kasrah, sebelum dan sesudahnya bukan sukun, dan setelahnya bukan hamzah,

e. Mad Tamkin(MTm), bertemunya dua huruf Ya, Ya pertama bertasydid dan berharakat kasrah sementara Ya 
kedua berharakat sukun,

f. Mad Lazim Mukhaffaf Harfi $(M L M k h H)$ adalah huruf-huruf tunggal yang disebut juga al-huruf alح، ي، ط، هـ، jberada di awal surat.

\section{Muammar Zainal Asyiqin}

MZA adalah qari internasional yang berasal dari Pemalang dengan banyak prestasi yang berhubungan dengan dunia qiraat Alquran, di antaranya menjuarai lomba tingkat nasional dan internasional pada dasawarsa 1980-an(Gade, 204:184185). Tabel berikut menunjukkan hasil analisis perhitungan Praat tiga besaran durasi dari masing-masing jenis mad.

Tabel 3

Durasi Mad 2 Harakat MZA

\begin{tabular}{ccccc}
\hline Jenis Mad & \multicolumn{3}{c}{ Durasi (d) } & $\begin{array}{c}\text { Rerata } \\
(\mathrm{d})\end{array}$ \\
\hline MT & 0,635 & 0,574 & 0,531 & 0.580 \\
MI & 0,947 & 0,718 & 0,963 & 0,876 \\
MB & 0,592 & 0,527 & 0,506 & 0,542 \\
MSS & 0,434 & 0,508 & 0,539 & 0,494 \\
MTm & 0,696 & 0,894 & 0,580 & 0,723 \\
MLMkhH & 1,226 & 1,087 & 1,035 & 1,116 \\
\hline \multicolumn{4}{c}{ Rerata Durasi Mad 2 Harakat } & 0,7218 \\
\hline
\end{tabular}

Sebagaimana ditampilkan pada tabel 3, masing-masing mad diambil contoh dari 3 ayat berbeda. Rerata durasi akhir diperoleh dari total rerata durasi semua jenis mad yang dibagi 6, yaitu 0,7218 dengan masing-masing rerata durasi adalah $0,580 \mathrm{~d}, 0,876 \mathrm{~d}, 0,542 \mathrm{~d}$, 0,494 d, 0,723 d, dan 1,116 d. Rerata masing-masing jenis mad berada padaangka di bawah 1 detik, kecuali pada MLMkhK. Pada MLMkhH, masingmasing data menunjukkan angka durasi di atas 1 detik.

\section{Maria Ulfah}

Maria Ulfah adalah salah seorang qariah dari Lamongan yang dikenal luas hingga ke luar negeri. Diadikenal dengan 'gelar' selebritasnya karena prestasinya di dunia qiraah (Becker, 2011:343). Dia merupakan wanita pertama yang memenangkan kompetisi internasional pembacaan Alquran di Malaysia pada
1980 (Doorn-Harder dan Feener, 2006:87).

Tabel 4

Durasi Mad 2 Harakat MU

\begin{tabular}{ccccc}
\hline Jenis Mad & \multicolumn{3}{c}{ Durasi (d) } & $\begin{array}{c}\text { Rerata } \\
(\mathrm{d})\end{array}$ \\
\hline MT & 0,655 & 0,567 & 0,702 & 0,645 \\
MI & 1,271 & 0,935 & 0,764 & 0,990 \\
MB & 0,699 & 0,646 & 0,684 & 0,676 \\
MSS & 0,694 & 0,607 & 0,627 & 0,643 \\
MTm & 1,369 & 0,497 & 0,581 & 0,816 \\
MLMkhH & 0,819 & 0,629 & 0,794 & 0,747 \\
\hline \multicolumn{4}{c}{ Rerata Durasi Mad 2 Harakat } & 0,7528 \\
\hline
\end{tabular}

Pada tabel 4, rerata akhir durasi kelompok mad 2 harakat MU adalah $0,7528 \mathrm{~d}$. Angka ini lebih besar dari rerata durasi kelompok mad 2 harakat MZA,0,7218 d, yaitu terpaut $0,031 \mathrm{~d}$. Namun, rerata durasi mad MLMkhH MZA tampak lebih besar dibandingkan rerata durasi jenis mad yang sama dari MU, yaitu MZA 1,116 d dan MU 0,747 d dengan selisih $0,369 \mathrm{~d}$.

\section{Durasi Mad yang Dibaca 2/4/6 Harakat \\ Mad yang termasuk dalam} kelompok ini adalah:

a. Mad 'Aridh lis-Sukun(MAlS) adalah mad Ashli yang terdapat di akhir ayat atau di akhir bacaan yang diwaqaf,

b. Mad Layyin (ML), apabila ada huruf layyin (و) dan (ي), setelahnya ada huruf mati yang disebabkan waqaf.

Tabel 5

Durasi Mad 2/4/6 Harakat MZA

\begin{tabular}{|c|c|c|c|c|}
\hline Jenis Mad & \multicolumn{3}{|c|}{ Durasi (d) } & $\begin{array}{l}\text { Rerata } \\
\text { (d) }\end{array}$ \\
\hline MAlS & 2,455 & 1,697 & 2,061 & 2,071 \\
\hline ML & 1,679 & 1,459 & 2,734 & 1,957 \\
\hline \multicolumn{4}{|c|}{ Rerata Durasi Mad 2/4/6 Harakat } & 2,014 \\
\hline
\end{tabular}

Rerata durasi kelompok mad 2/4/6 harakat MZA diperoleh dari pembagian total rerata durasi dari 2 jenis mad. Pada tabel 5, rerata akhirnyaadalah 2,014 d. Durasi rerata masing-masing jenis mad 
adalah $2,071 \mathrm{~d}$ dan $1,957 \mathrm{~d}$.

Tabel 6

Durasi Mad 2/4/6 Harakat MU

\begin{tabular}{|c|c|c|c|c|}
\hline Jenis Mad & \multicolumn{3}{|c|}{ Durasi (d) } & $\begin{array}{l}\text { Rerata } \\
\text { (d) }\end{array}$ \\
\hline MAl & $\begin{array}{c}3,07 \\
6\end{array}$ & $\begin{array}{c}2,86 \\
9\end{array}$ & 1,416 & 2,454 \\
\hline ML & $\begin{array}{c}2,94 \\
9\end{array}$ & $\begin{array}{c}3,17 \\
5\end{array}$ & 2,278 & 2,801 \\
\hline \multicolumn{4}{|c|}{ Rerata Durasi Mad 2/4/6 Harakat } & 2,6275 \\
\hline
\end{tabular}

Tabel 6 menampilkan durasi masing-masing mad dalam kelompok mad 2/4/6 harakat MU. Rerata durasi akhir adalah 2,6275 d yang diperoleh dari total durasi kedua jenis mad dibagi 2. Perbedaan yang terpaut dengan rerata durasi kelompok jenis mad ini dari MZA adalah $0,6135 \mathrm{~d}$. Perbedaan rerataakhir durasi kelompok mad tersebut tampak tidak jauh berbeda. Akan tetapi, jika dibandingkan rerata jenis mad ML antara MZA dan MU, perbedaan yang muncul terpaut cukup jauh, yaitu hampir 1 detik (0,8544 d) dengan MZA 1,957 d, sedangkan MU 2,801 d. Selain itu, data durasi pada MAlS antara MZA dan MU memiliki perbedaan yang cukup besar. Perbedaan durasi tersebut mencapai $1,172 \mathrm{~d}$, yaitu selisih antara data kedua pada MAlS. Begitu juga pada ML. Perbedaan durasi yang terpaut pada masing-masing dataadalah $1,270 \mathrm{~d}$, $1,716 \mathrm{~d}$, dan $0,456 \mathrm{~d}$ dengan data pertama dan kedua durasi MU lebih panjang dibandingkan durasi MZA dan pada data ketiga, durasi MZA lebih panjang 0,456 d dari durasi MU.

\section{Durasi Mad yang Dibaca 4-5 Harakat}

Kelompok jenis mad ini adalah :

a. Mad Wajib Muttashil (MWM), mad Ashli yang bertemu hamzah dalam satu kata,

b. Mad Jaiz Munfashil (MJM) adalah mad Ashli yang bertemu hamzah dalam dua kata,

c. Mad Shilah Kubra (MSK), ha' dhamir yang berharakat dhammah atau kasrah, sebelum dan sesudahnya bukan sukun, dan setelahnya bertemu hamzah.

Tabel 7

Durasi Mad 4-5 Harakat MZA

\begin{tabular}{ccccc}
\hline Jenis Mad & \multicolumn{2}{c}{ Durasi (d) } & $\begin{array}{c}\text { Rerata } \\
\text { (d) }\end{array}$ \\
\hline MWM & 1,592 & 1,893 & 1,522 & 1,669 \\
MJM & 1,646 & 1,523 & 1,737 & 1,635 \\
MSK & 1,568 & 1,972 & 1,589 & 1,709 \\
\hline \multicolumn{4}{c}{ Rerata Durasi Mad 4-5 Harakat } & 1,671 \\
\hline
\end{tabular}

Tabel di atas menampilkan durasi masing-masing mad dalam kelompok mad 4-5 harakat MZA. Rerata durasi akhir adalah 1,671 d, diperoleh dari total rerata ketiga mad dibagi 3 , dengan rerata masing-masing jenis mad adalah 1,669 d, $1,635 \mathrm{~d}$, dan $1,709 \mathrm{~d}$.

Tabel 8

Durasi Mad 4-5 Harakat MU

\begin{tabular}{ccccc}
\hline Jenis Mad & \multicolumn{2}{c}{ Durasi (d) } & $\begin{array}{c}\text { Rerata } \\
\text { (d) }\end{array}$ \\
\hline MWM & 2,841 & 2,836 & 1,804 & 2,494 \\
MJM & 2,053 & 1,818 & 1,806 & 1,892 \\
MSK & 1,889 & 1,396 & 1,883 & 1,723 \\
\hline Rerata Durasi Mad 4-5 Harakat & $\mathbf{2 , 0 3 6 3}$ \\
\hline
\end{tabular}

Rerata durasi kelompok mad 4-5 harakat MU adalah 2,0363 d. Hal ini sedikit lebih besar jika dibandingkan dengan MZA yang berada padaangka 1,671 d. Namun demikian, rerata durasi jenis mad MWM terpaut cukup jauh antara kedua qari tersebut. Rerata MWM dari MZAadalah 1,669 d, sementara MU 2,494 d. Selisih perbedaannyaadalah 0,825 d. Selain itu, dari ketiga durasi jenis MWM, dua di antaranya memiliki selisih perbedaan yang cukup signifikan dengan durasi MU lebih lama. Durasi MWM dari MZA masing-masing adalah 1,592 d, 1,893 d, dan 1,522 d. Sedangkan durasi jenis mad yang sama dari MU adalah 2,841 d, 2,836 d, dan 1,804 d. Masingmasing selisih yang terpaut adalah 1,249 d, 0,943 d, dan 0,282 d. Durasi MWM dari MU jauh lebih panjang jika dibandingkan dengan MZA pada data durasi yang pertama. Perbedaan durasi 
MWM MU dari masing-masing data juga memiliki selisih yang cukup jauh, yaitu antara data pertama/kedua dengan data ketiga. Selisihnya mencapai 1,037 d.

\section{Durasi Mad yang Dibaca 6 Harakat} Kelompok jenis mad ini terdiri atas :

a. Mad Lazim Mukhaffaf Kilmi (MLMkhK), huruf hamzahistifham (yang artinya 'apakah' atau 'mengapa') yang disambut oleh hamzah yang bertanda sukun, atau mad lazim yang bertemu dengan alif lamqamariyah,

b. Mad Lazim Mutsaqqal Kilmi (MLMtsK), mad Ashliyang diikuti oleh huruf bertasydid (geminasi) dan terjadi pada 1 kata,

c. Mad Lazim Mutsaqqal Harfi(MLMtsH), huruf mad yang bertemu sukunAshli pada huruf muqatha'ah dan di-idghamkan ke huruf setelahnya sehingga menjadi bertasydid,

d. Mad Farq (MF), mad yang membedakan hamzahistifham dengan hamzah lainnya, atau mad yang terjadi ketika mad lazim bertemu dengan huruf syamsiyah.

Tabel 9

Durasi Mad 6 Harakat MZA

\begin{tabular}{|c|c|c|c|c|}
\hline Jenis Mad & \multicolumn{3}{|c|}{ Durasi (d) } & $\begin{array}{l}\text { Rerata } \\
\text { (d) }\end{array}$ \\
\hline MLMkhK & 3,071 & 2,965 & & 3,333 \\
\hline MLMtsK & 1,932 & 2,099 & 2,959 & 2,330 \\
\hline MLMtsH & 2,054 & 3,238 & 2,417 & 2,569 \\
\hline MF & 1,431 & 2,273 & 2,369 & 2,024 \\
\hline \multicolumn{4}{|c|}{ Rerata Durasi Mad 6 Harakat } & 2,564 \\
\hline
\end{tabular}

Tabel 9 menunjukkan bahwa rerata durasi mad pada kelompok mad 6 harakat MZAadalah 2,564 d. Adapun pada mad MLMkhK hanya ditampilkan 2 contoh karena dalam Alquran, mad tersebut hanya terdapat pada dua tempat yaitu pada QS 10:51 dan QS 10:91. Perbedaan durasi antara MLMkhK dengan jenis mad lainnya terpaut sangat jauh. Jika dibandingkan dengan MLMtsK, selisih yang muncul adalah sekitar 1 detik, hampir sama dengan MLMtsH. Sementara itu, dibandingkan dengan MF, selisih yang ada mencapai $1,640 \mathrm{~d}$.

Tabel 10

Durasi Mad 6 Harakat MU

\begin{tabular}{|c|c|c|c|c|}
\hline Jenis Mad & \multicolumn{3}{|c|}{ Durasi (d) } & $\begin{array}{l}\text { Rerata } \\
\text { (d) }\end{array}$ \\
\hline MLMkhK & 3,295 & 2,631 & & 2,963 \\
\hline MLMtsK & 1,967 & 2,111 & 2,541 & 2,206 \\
\hline MLMtsH & 2,952 & 2,913 & 2,755 & 2,873 \\
\hline MF & 2,757 & 2,732 & 2,777 & 2,755 \\
\hline \multicolumn{4}{|c|}{ Rerata Durasi Mad 6 Harakat } & 2,699 \\
\hline
\end{tabular}

Sebagaimana pada tabel 9, tabel 10 hanya menampilkan duacontoh pada mad MLMkhK. Tabel 10menunjukkan bahwa rerata durasi mad MU pada kelompok mad 6 harakat adalah 2,699 d, 0,135 d lebih panjang dari durasi mad MZA. Selisih ini tampak sangat kecil jika dibandingkan dengan selisih yang terjadi pada data tabel 8 dan 9. Namun demikian, durasi dan rerata durasi jenis MF antara MZA dan MU terpaut cukup jauh. Durasi MU jauh lebih lama dibandingkan dengan durasi MZA. Durasi pada data MF terpaut hingga 1,326 d. Hal ini tampak sama seperti perbedaan yang ada pada jenis MWM pada tabel 7 dan 8. Sementara itu, rerata durasi MF juga terpaut cukup jauh, yaitu $0,731 \mathrm{~d}$.

Hal menarik lainnyaadalah jika data pada tabel 8 dibandingkan dengan data pada jenis kelompok mad 6 harakat, tampak bahwa durasi MWM (kelompok mad 4-5 harakat) MU lebih besar daripada durasi jenis MLMtsK yang juga diujarkan MU pada kelompok mad 6 harakat.

\section{Kesimpulan}

Berdasarkan temuan dalam analisis di atas, beberapa kesimpulan yang dapat diambil adalah: Pertama, durasi kelompok mad 2 harakat berkisar antara 0,7-0,8 detik, durasi kelompok mad 2/4/6 harakat berkisar antara 2-3 detik, durasi kelompok mad 4-5 harakat berada padakisaran 1,62,5 detik, serta durasi kelompok mad 6 harakat antara 2,5-3 detik. Kedua, secara umum, durasi bacaan mad perempuan 
lebih lama daripada durasi bacaan mad laki-laki. Hal ini berbeda dengan temuan penelitian yang dilakukan oleh Pranoto (2018) yang mengemukakan bahwa durasi suara laku-laki lebih lama dari durasi perempuan.

Penelitian mengenai durasi bacaan Alquran menjadi menarik untuk dikaji. Pertanyaan yang muncul selanjutnyaadalah bagaimana prosodi yang ideal digunakan sebagai acuan dalam membacaAlquran? Untuk menjawab pertanyaan tersebut, perlu dilakukan kajian yang lebih mendalam.

\section{Daftar Pustaka}

Ahmad, Abu (2017). Mengenal Artificial Intelligence, Machine Learning, Neural Network, dan Deep Learning. Tersedia di https://www.researchgate.net/public ation/320395378 Mengenal Artific ial_Intelligence_Machine_Learning Neural Network dan Deep Lear ning diakses pada 13 Maret 2019.

Becker, Judith(2011). Epilogue. David D. Harnish dan Anne K. Rasmussen. Divine Inspirations: Music and Islam in Indonesia. New York: Oxford University Press hlm 337354.

Bengio, Yoshua (2009). Learning Deep Architectures for AI. Foundations and Trends in Machine Learning II (1): 1-127. Boston: Now Publishers.

Bengio, Yoshua, Goodfellow, Ian J., dan Courville Aaron (2015). Deep Learning. Amerika Serikat: MIT Press.

Boersma, Paul dan van Heuven, Vincent (2001). Speak and unSpeak with Praat. Glot International V (9/10): 1-7.

Crystal, David (2008). A Dictionary of Linguistics and Phonetics. Oxford: Blackwell Publishing.

Doorn-Harder, Nelly van dan R. Michael
Feener (2006). Indonesia. Kathryn M. Coughlin. Muslim Culture Today: A Reference Guide. Connecticut: Greenwood Press hlm 77-88.

Gade, Anna M (2004). Perfection Makes Practice: Learning, Emotion, and the Recited Quran in Indonesia. Honohulu: Universitu of Hawai'i Press.

Hiluz, Abdullah Abdul Qadir. (2008). AlMuyassar al-Mufid fi 'Ilm atTajwid. Oman: Mamlakah alUrduniyah al-Hasyimiyah.

Al-Khu>li, Muhammad 'Ali. (1982). Mu'jam 'Ilmul-'Aswa>t. Riyadh: Mut\}a>biq al-Farazdaq a'tTijariyyah.

Marsono (2013). Fonetik. Yogyakarta: Gadjah Mada University Press.

Pranoto, M. Sholihin (2018). Analisis Frekuensi, Durasi, dan Intensitas Suara Laki-laki dan Perempuan Jawa Menggunakan Perangkat Lunak Praat. Lingua XIV (2): 190199.

Sugiyono (2003). Pedoman Penelitian Bahasa Lisan:Fonetik. Jakarta: Pusat Bahasa.

Tsukada, Kimiko (2009). An Acoustic Comparison of Vowel Length Contrasts in Arabic, Japanese, and Thai: Durational and Spectral Data. International Journal on Asian Language Processing XIX (4): 127138

Yaman, Khoirul Jamil M (2016). Modus Tuturan Bahasa Arab oleh Pembelajar Bahasa Arab di Medan: Kajian Fonetik Eksperimental. Disertasi. Medan: Universitas Sumatera Utara.

Zangar, Imene, dkk (2018).Duration Modeling Using DNN for Arabic Speech Synthesis. Speech Prosody: 597-601. International Speech Communication Association. 